\title{
Trading Interactions: Supplier Empathy, Consensus and Bias
}

\author{
Alistair Brandon-Jones \\ Lecturer in Operations and Supply Management \\ School of Management \\ University of Bath \\ Claverton Down \\ Bath \\ BA2 7AY \\ abj20@bath.ac.uk
}

\begin{abstract}
Alistair Brandon-Jones is a lecturer in operations and supply management at Bath University and a visiting lecturer at Warwick Medical School. Previously, he was a teaching fellow at Warwick University and a visiting lecturer at the University of San Diego. Alistair's main research considers how procurement functions can change the way they operate to meet the needs of their internal customers.
\end{abstract}

John Ramsay

Reader

The Business School

Staffordshire University

Leek Road

Stoke-on-Trent

ST4 2DF

j.ramsay@staffs.ac.uk

Fax: 01782747006

j.ramsay@staffs.ac.uk

(corresponding author)

John Ramsay is a Reader in Purchasing and Management at the Business School of Staffordshire University. His business experience includes a decade as a purchasing manager in the automotive supply industry. His research interests include Buyer-Supplier interactions and Purchasing's strategic contribution.

Beverley Wagner

Senior Lecturer 
Department of Management

University of Strathclyde

173 Cathedral Street

Glasgow G4

beverly.wagner@strath.ac.uk

Beverly Wagner is a senior lecturer in the Department of Marketing, University of Strathclyde. Since 1996, she has been involved in research into formation and implementation of partnering and business alliances in the Drinks and Packaging sector, also in the Microelectronics and Oil and Gas Industries. Her research interests include customer-supplier relationships, inter-organisational cooperation, and logistics and supply chain management. 


\section{Trading Interactions: Supplier Empathy, Consensus and Bias}

\section{Abstract}

Purpose - The paper explores the nature of buyer's attitudes towards the partial consensus surrounding the benefits of buyer-supplier cooperation - the relational exchange perspective. The extent to which buyers display an awareness of, and willingness to respond positively to, supplier needs, wants and preferences termed Supplier Empathy - and how this represents their attitude towards buyer-supplier cooperation and support of relational exchange is empirically assessed. In addition, factors that may influence levels of supplier empathy and the effect of supplier empathy on the incidence of supplier problems are examined. Finally, the extent to which social acceptability bias may mask attitudes in areas where consensus exists is considered.

Design / Methodology / Approach - An empirical study utilising survey data from members of the Chartered Institute of Purchasing and Supply in the UK was completed. A total, 421 useable responses were received and analysed to evaluate hypotheses. The design also included efforts to identify the presence and minimise the effects of social acceptability bias.

Findings - The analysis indicates that the partial consensus surrounding the relational exchange approach is not shared by all practitioners. In addition, it was found that the level of supplier empathy exhibited by respondents is significantly influenced by supplier-dependence aversion, innovation focus, extent of codesign activity, existence of explicit partnership / cooperation objectives, and support for long-term trading relationships. The findings also indicate that buyers, regardless of business size, who display high levels of supplier empathy also report a reduced incidence of supplier problems. Finally, the presence of social acceptability bias was detected, thus suggesting that where present, respondents' negative attitudes towards the cooperative buyer-supplier relationships may actually have been under-reported.

Research limitations / implications - The study highlights the need for academics to be aware of the possible distorting effects of subject consensus, and research designs should seek to minimise the effects of social acceptability bias. The analysis also suggests that organisations wishing to embrace a cooperative trading culture may benefit from training to increase levels of supplier empathy.

Originality / value - The paper presents evidence that despite a significant but partial co-operation consensus in the academic literature, many large company practitioners appear unconvinced of the benefits of cooperation. Most analyses of buyer attitudes and behaviours are conducted by Marketing researchers seeking to assist organisations-as-suppliers. This research is intended to help companies improve their performance as buyers. The paper also includes a rare attempt to identify and deal with the effects of social acceptability bias in the Operations and Supply Management field.

Keywords - Supplier Empathy, Relational Exchange, Social Acceptability Bias

Paper type - Research paper 


\section{Introduction}

There are a large number of published papers in the Purchasing and Supply Management field concerning the management of inter-company trading relationships. Many actively promote or tacitly support the suggestion that cooperation is better than competition and that buyer-supplier partnerships are desirable (cf. Jonsson and Zineldin, 2003; Matopoulos et al., 2007). One of the underlying assumptions of the partial consensus identified in the literature is that the adoption of a cooperative approach will elicit superior supplier performance (Emberson and Story, 2006). However, there are also dissenting voices in the academic world who argue against the singling out of any one "best" form of trading relationship (cf. Cox et al., 2005), and some evidence that any cooperation consensus is not shared by practitioners (cf. Hughes and Weiss, 2007). It would appear, therefore, that there may be a mis-match between the majority recommendations of academe and practitioner behaviour in this subject area. An investigation of this possible mis-match forms the stimulus and rationale for this study.

Drawing on Relational Exchange theory (Heide, 1994; Joshi and Stump, 1999), the paper explores the extent to which practitioners support a widespread but partial consensus concerning the benefits of buyersupplier cooperation. Drawing on a variety of sources, buyer-supplier cooperation is described as relationships based on mutual trust and openness in which participating parties agree to invest resources, mutually achieve goals, share information and undertake joint problem solving in order to achieve improved performance and competitive advantage (Ring and Van de Ven 1994; Spekman et al., 1998; Wagner et al., 2002; Soosay et al., 2008). It is argued that buyer concern for, and satisfaction of, supplier needs, preferences and interests is one logical and likely outcome of buyer support for any widespread cooperation consensus. Consequently, the term 'Supplier Empathy' is introduced as an external behavioural representation of this kind of buyer attitude. Supplier empathy can be described as the propensity of a buyer to display an awareness of, and willingness to respond positively to, supplier needs, wants, preferences and overall welfare.

The study empirically examines whether buyers display supplier empathy in practice and to what extent this shows support for a co-operation consensus. The paper also investigates a number of factors that may influence the degree of supplier empathy and the relationship between supplier empathy and the incidence of supplier problems. Finally, it is argued that the existence and strength of any widespread consensus increases the likelihood of Social Acceptability Bias (Randall et al., 1993) prompting respondents to offer exaggeratedly positive responses to questions probing their attitudes towards trading cooperation and thus undermining the validity of any findings. Thus, the paper addresses the following four research questions:

1) To what extent do practitioners support a widespread but partial consensus concerning the benefits of buyer-supplier cooperation?

2) What factors influence the degree of supplier empathy displayed by buyers? 
3) Is there a relationship between the presence of supplier empathy and the incidence of supplier problems?

4) Is social acceptability bias present in the respondents' answers?

The main contribution of the research is the finding that buyers, regardless of business size, who show an interest in and willingness to respond to, their supplier's needs (i.e. display supplier empathy) report a reduced incidence of problem suppliers. This, in conjunction with findings indicating factors that appear to influence buyer attitudes towards cooperation with suppliers may be employed by firms eager to improve the quality of their interactions with upstream supply chain members. The paper also includes a rare attempt to identify and deal with the effects of social acceptability bias in the Operations and Supply Management field.

The paper proceeds as follows. Firstly, there is an examination of the literature relating to relational exchange theory, the extent to which consensus supporting this approach to buyer-supplier relationships exists, and the risk posed by social acceptability bias in this area. Hypotheses are then developed concerning factors that may influence the level of supplier empathy displayed by buyers, and its affect on trading relations. Secondly, the methodology for the study is described in detail. Thirdly, an analysis of survey data and hypotheses is provided. Finally, conclusions are drawn including the implications for theory and practice, research limitations, and opportunities for further research.

\section{Literature Review}

\section{Relational exchange}

The concept of Relationship Marketing (See Pillai and Sharma, 2003 for a historical review) and the burst of research into the management of buyer-supplier relationships that occurred in the 1990s, emerged from applications of Transaction Cost Economic theory (Williamson 1975, 1985, 1991) in the Marketing field (cf. Rindfleisch and Heide, 1997). From a transaction cost perspective, all firms have the goals of:

a) Finding methods of managing and controlling the process of inter-company trading governance mechanisms

b) Minimising the costs of managing that process - governance costs, and

c) Preventing the companies they trade with behaving in a self-interested manner and seeking to maximise the benefit they gain from the trading relationship at the expense of the company they are trading with - opportunism.

Governance mechanisms vary across a spectrum from spot markets at one extreme, to unified authority structures, vertical hierarchies or firms at the other (Williamson, 1985). Joshi and Stump (1999) point out that ranged between these two extremes are a variety of buyer-supplier trading arrangements including “...joint ventures, joint action relationships, value-added partnerships, working partnerships, franchise arrangements, relational exchanges, research consortia and networks" (p. 335), all of which can be seen to be forms of cooperative governance mechanism. Much of the task of exploring the practical management 
implications of the problems faced by companies trying to manage such "middle range", bilateral or hybrid governance structures has been carried out to date by researchers in the Marketing field.

Relational Exchange Theory (Heide, 1994; Artz, 1999; Joshi and Stump, 1999; Brown et al., 2000) draws on the seminal contract law work of Macneil (1980) which defines the concepts of transactional and relational contracting. The former relate to spot market interactions and the latter to trading arrangements which tend to be "long-term, cooperative, and guided by expectations of repeated transactions" (Provan and Gassenheimer, 1994), and in which the trading parties subsume their own utility function in the interests of the global utility of the system through "joint accomplishments" (Joshi and Stump, 1999).

The influence of relational exchange theory is particularly noticeable in the Operations and Supply Management field in Purchasing-focused work where there has been considerable interest in its application in two sectors that experience significant problems of contract formation and management - the construction industry (Kumutasawamy et al., 2005; Gil, 2008; Rahman and Kumutasawamy, 2008) and the public sector (Parker and Hartley, 2003; Lian and Laing, 2004; Davis, 2007; Zheng et al., 2008). There has also been exploration of the implications for E-Auctions (Tunca and Zenios, 2006; Pearcy et al., 2007), communication (Larson et al., 2005), the semiconductor industry (Bolton et al., 1994), supplier performance (Fink et al., 2007), just-in-time purchasing (Buvik and Halskau, 2001), outsourcing (Nesheim, 2001) and of the role played by trust (Jeffries and Reed, 2000; Claro et al., 2006).

At the heart of relational exchange theory lies the use of "relational norms" as a form of governance mechanism employed to limit opportunism (Moschandreas, 1997) and encourage commitment to the ongoing trading relationships (Brown et al., 2000). Relational exchange norms are shared expectations about behavior conducive to cooperative trading relations (Heide and John, 1992), and include joint planning and problem solving (Claro et al., 2003), harmonious conflict resolution (Gundlach et al., 1995), problem solving (Claro et al., 2003) and commitment (Provan and Gassenheimer, 1994). Joshi and Stump (1999) argue that, unlike markets where behaviour is controlled by incentives, or vertical heirarchies where fiat is the control mechanism of choice, in relational exchange relationships behavior is determined by moral control (Larson, 1992) through internalization (Kelman, 1958). Buyers and suppliers engaged in relational exchange thus internalise relational norms and control their own behaviour.

In the study below, evidence of buyer support for the relational exchange approach is sought in their behaviour towards suppliers. Thus buyers may use a variety of rewards and punishment to try to elicit what they consider to be appropriate supplier behaviour. Rewards might include such things as longer leadtimes, better planning information and higher prices, whilst punishments include the withdrawal of payments, threats of re-sourcing and so on. Buyers who enthusiastically embrace the relational exchange approach will tend to focus on supplier rewards and avoid punishments, not least because punishments and genuine cooperation are incompatible. It is, for example, deeply inadvisable to punish suppliers if you are seeking harmonious conflict resolution or wish them to display wholehearted commitment to a trading relationship. Similarly, one may argue that buyers who repeatedly seek to allocate blame to suppliers when relationships sour or there are supply performance failures, are displaying a lack of interest in the relational 
exchange approach. Such buyer behaviour is, for example, extremely unlikely to foster bilateral information sharing or joint planning and problem solving. At root, one of the main differences between a buyer who genuinely embraces the relational exchange approach and one who does not is that the former will be concerned to maximise the benefits suppliers obtain from the exchange as well as their own. To use the terminology of negotiation theory, such buyers will be interested in the joint-problem solving, value creating approach of integrative negotiation (Allred, 2000; Lewicki et al., 2006). They will, in short, feel empathy for their suppliers' needs, wants, preferences and overall welfare, and moreover be prepared to act in ways intended to satisfy those needs, wants, preferences and overall welfare. The propensity of a buyer to display an awareness of, and willingness to respond positively to, supplier needs, wants, preferences and overall welfare may thus be called their degree of "Supplier Empathy". Buyers who display a high degree of supplier empathy are logically more likely to embrace the relational exchange approach than those with a lower degree of empathy. In order to determine the link between supplier empathy and attitudes towards the relational exchange approach a review of literature follows. The review demonstrates the existence of a widespread, but partial, consensus supporting cooperation between buyers and suppliers.

\section{The cooperation consensus}

Relational exchange represents the most cooperative extreme of the range of relationship types described by Macneil (1980). Ten years later, Heide and John (1990) observed that at the beginning of the 1990s in the Marketing field, "practice-oriented reporting" almost without exception tends to view “...closer relationships as a universally desirable idea" (p. 34). Similar, albeit less than universal, sentiments can be detected in the field of Operations and Supply Management. Table $\mathbf{1}$ below shows the results of a search of a range of journals for papers dealing with buyer-supplier interactions. The search used the keywords “cooperation”, “cooperative”, “collaboration”, “collaborative”, “alliances”, "partnerships”, "relational exchange", and "contracting", paired with "buyer-supplier" and/or "purchasing" as required. Papers dealing with buyer-supplier relationships have been published in a wide range of fields and a comprehensive literature search of all work on that topic would be unwieldy. Consequently the search focused on journals with a record of publishing work with a Purchasing rather than Marketing perspective, i.e. where the main focus of the work is on the effects of the phenomenon being analysed on the welfare of the buying organisation. Target journals included International Journal of Operations and Production Management, Journal of Operations Management, Journal of Purchasing and Supply Management, European Journal of Purchasing and Supply Management, International Journal of Purchasing and Materials Management, Journal of Supply Chain Management, and Supply Chain Management: An International Journal. Many papers inevitably covered several topics. Therefore, work was recorded where a discussion of buyersupplier cooperation/partnerships/alliances/collaboration or the relational approach played a role in the paper's argument. Although the particular descriptive terms used varied in different papers, for simplicity we have used the phrase "buyer-supplier cooperation" throughout in the subject column of Table 1. The 
topics that have been linked to discussions of this kind of cooperation include: Strategy (for example Macbeth 2002; Su et al., 2008); New products and R\&D (for example Mishra \& Shah 2009); Production control (for example Perez \& Sanchez, 2001); Quality (for example Kannan and Tan, 2004); JIT (for example Gupta, 1990; Gonzalez-Benito \& Spring, 2000); and Outsourcing (for example Hancock and Oates, 2001; Shook, et al., 2009). The frequency with which each subject has been discussed is shown in

Table 1.

Table 1. Buyer-supplier cooperation search results summary

\begin{tabular}{|c|c|}
\hline$\underline{\text { Topic }}$ & $\underline{\text { Article Frequency }}$ \\
\hline Achieving/Improving buyer-supplier cooperation & 28 \\
\hline Reasons for failure/tackling problems/barriers to buyer-supplier cooperation & 13 \\
\hline General support for buyer-supplier cooperation & 22 \\
\hline Strategy and buyer-supplier cooperation & 5 \\
\hline Costs and benefits of buyer-supplier cooperation & 3 \\
\hline Small companies and buyer-supplier cooperation & 5 \\
\hline New products/R\&D and buyer-supplier cooperation & 3 \\
\hline Production Control and buyer-supplier cooperation & 2 \\
\hline Competition combined with buyer-supplier cooperation & 3 \\
\hline E-procurement and buyer-supplier cooperation & 4 \\
\hline Negotiating and buyer-supplier cooperation & 1 \\
\hline Logistics and buyer-supplier cooperation & 1 \\
\hline Quality and buyer-supplier cooperation & 3 \\
\hline Outsourcing and buyer-supplier cooperation & 3 \\
\hline Power and buyer-supplier cooperation & 1 \\
\hline Social Capital and buyer-supplier cooperation & 2 \\
\hline JIT and buyer-supplier cooperation & 4 \\
\hline Supplier performance and buyer-supplier cooperation & 1 \\
\hline Strategy and buyer-supplier cooperation & 3 \\
\hline Supplier selection and buyer-supplier cooperation & 2 \\
\hline Partnership and buyer-supplier cooperation & 3 \\
\hline TOTAL $=$ & 112 \\
\hline
\end{tabular}

Given the relatively small number of journal titles in the Operations and Supply Management field that deal with the purchasing-related implications of buyer-supplier cooperation, this group of papers represents a significant body of work. Moreover, it would appear that awareness of the benefits of such cooperation may be accelerating in the US where, in a recent review of Supply Chain literature covering the period 1997 to 2006 and examining publication frequency by topic, "Supplier Alliances/Relationships" came third from top, and the authors observed: 
"The resurgence of publications in this area over the past 5 years is surely a result of a general trend within industries of moving away from simple transaction and contractual-based relationships, and toward more long-term relational forms of collaboration between parties involved in supply chain activities."

Giunipero and Hooker, 2008, p. 76

The extent to which each paper contributing to Table 1 may be compared with arguments in support of the relational exchange approach is not always clear-cut. For example, Frohlich and Westbrook (2001) argue that the benefits to company performance from increased cooperation with suppliers only appears to have occurred if the company behaved in a similar manner with customers. Liu et al. (2009) argue that firms should adopt both the transactional and relational approaches. Elsewhere, others in the field overtly advocate the use of competition. For example, Ramsay and Wilson (1990) argue against the use of singlesourcing, Lau and Lau (1994) discuss dual-sourcing, and Caldwell et al. (2005) discuss the practice and benefits of competitive behaviour. Moreover, there have been some papers developing analyses that favour neither competition nor cooperation. The cluster of scholars around Andrew Cox in the UK, for example, has produced a stream of work arguing that no one relationship type can be regarded as "best" (Cox et al., 2003 and 2005). The IMP group has also consistently promoted consideration of a range of different relationships (Wilkinson and Young, 1994; Ford, 1997) as have Bensao (1999), Mollering (2003), Saccani and Perona (2007) and Howard et al. (2007). Ramsay (1996) offers a direct critique of the widespread cooperation consensus. Finally, empirical evidence has emerged suggesting that some practitioners are less than enthusiastic about the supposed benefits of buyer-supplier cooperation (cf. Dyer et al., 1998; Ramsay, 2004; Hughes and Weiss, 2007).

The fact that the agreement is not universal is hardly surprising. Research has revealed the difficulties of generating consensus around an idea within an individual organisation (Kijkuit and van den Ende, 2007), and shown that consensus formation is negatively correlated with both the size (Smith et al., 1994) and diversity (Knight et al., 1999) of the group involved. It would be truly remarkable therefore, if a disparate group of practitioners in a variety of industries and academics with backgrounds in a number of fields were all to embrace such a consensus.

In summary, it appears that there is a well established, widespread, albeit partial consensus concerning the positive benefits of cooperative buyer-supplier interactions. This may have taken on the status of a "conventional wisdom" (Galbraith, 1977) that influences the attitudes and beliefs of buyers and suppliers. At the same time, evidence has emerged of a possible divergence between the partial consensus and some of the most prevalent forms of buyer-supplier interaction in practice (cf. Snell, 2007). 


\section{Social acceptability bias}

There is an epistemological problem associated with the conduct of empirical research into a subject around which a degree of consensus has formed. Some respondents will be susceptible to social acceptability bias and this may seriously reduce the validity of their responses. Social acceptability bias is a form of common method bias or variance (Podsakoff et al., 2003) that arises from the tendency of some individuals, in responses to self-report instruments, to over-report the incidence of their own behaviour that is regarded as socially desirable, and under-report behaviour that is less desirable (Phillips and Clancy, 1972; Randall et al., 1993). Where some kind of consensus exists, respondents who are both susceptible to social acceptability bias and aware of the consensus are likely to give exaggeratedly positive responses to any questions whose responses can be interpreted as indicating approval for that consensus. The presence of the bias thus casts doubt on the validity of any data collected.

In this context, where a long-standing, albeit partial consensus about the benefits of relational exchange exists, one may predict that questions in surveys or interviews requiring respondents to describe their attitudes towards buyer-supplier cooperation, partnerships, trust, commitment and so on may elicit some biased, unreliable responses. The problem will be particularly acute if, as in this case, one of the research objectives is to search for respondent disagreements with the prevailing partial consensus. There is limited discussion of how to identify and deal with the effects of social acceptability bias in the Business field (King and Bruner, 2000), and even less in Purchasing and Supply Management (See Da Silveira and Arkader, 2007, for a rare treatment). However, a body of research, primarily in the fields of Psychology and Consumer Marketing indicates that the effects of the bias may be reduced if indirect questions about the subject matter are employed (Armascott et al., 1991; Fisher, 1993; Fisher and Tellis, 1998). Secondly, a web-based approach to data collection has been shown to reduce social acceptability bias when compared with face-to-face interviews (Richman et al., 1999) and to encourage respondent honesty (Thach, 1995), reduce inhibitions (Boshier, 1990) and result in respondent behaviour becoming more “...extreme, more impulsive and less socially differentiated..." (Nancarrow and Brace, 2000, p. 1497).

\section{Hypotheses development and conceptual model}

In this section we explore a number of factors that may influence the level of support for the relational exchange perspective and set out hypotheses to test their possible effects on the level of supplier empathy.

We also examine how supplier empathy may influence supplier performance.

\section{Supplier dependence aversion}

The partnerships, strategic supplier alliances and the like encouraged by the relational exchange approach all generate increased dependence for the organisations involved. Although there has been quite extensive 
research into the effects of dependence in buyer-supplier relationships, there is little emphasis on the fact that dependence is often perceived as unpleasant for buyers. Increased asset specificity, for example, tends to increase dependence and “....asset specificity and opportunism are positively related" (Joshi and Stump, 1999). Provan and Skinner (1989) conclude that because low dependence relationships are not supportive or cooperative, highly dependent suppliers will behave less opportunistically. Research in Psychology has shown that dependence leads individuals to experience anxiety about either the continued satisfaction of needs (Bersheid and Fei, 1977; Attridge et al., 1998) or the effects of possible future abandonment (Davilla and Bradbury, 2001). In one test of these ideas in joint ventures, it was found that increased dependence had a negative effect on both organisations' feelings of security (Robson et al., 2006). Ryu et al. (2007) find that buyers regarding themselves as the dependent party in relationships tend to rely more on supplier monitoring and control mechanisms. Moreover supplier failures generate conflict with buyers' internal customers (Lonsdale and Watson, 2005; Croom and Brandon-Jones, 2007). Buyers may believe that supplier failures are less likely to occur, and easier to rectify when they do, if the supplier is dependent on the buyer. For all of these reasons one may argue that some buyers may try to avoid relational exchange and the increased dependence that it necessarily entails. The condition of a buyer being dependent on a supplier may be called 'supplier-dependence', and buyers may, in other words, become averse to increased supplier-dependence, hence:

\section{H1: The higher the degree of supplier-dependence aversion, the lower will be the degree of supplier empathy.}

\section{Innovation focus}

Innovation may require transaction-specific investments by both parties. Heide and John (1990) argue that close relationships emerge as responses to the need for safeguarding transaction-specific assets and adapting to uncertainty while Song and Di Benedetto (2008) note that increased supplier involvement increases new product performance and increased asset specificity increased the level of supplier involvement. Carr et al. (2008) suggest that supplier involvement in new product development increased with increases in supplier dependence, while Soosay et al. (2008) argue that collaborative relationships enhance innovation and improve strategic focus. Thus, organisations that focus on innovation and new products as a primary source of sustainable competitive advantage may favour the relational exchange approach in pursuit of the benefits of supplier innovations (Treacy and Wiersema, 1993, Prajogo et al, 2004; Owen et al., 2008). Alternatively, some organisations with a focus on cost may also support the same perspective to achieve cost-savings through lean supply methods. On balance, we suggest the following hypothesis: 


\section{H2: Respondents with strategic objectives focused on innovation will display higher levels of supplier empathy than those with other strategic foci.}

\section{Co-design}

One possible outcome of buyer support for relational exchange may be an increase in the incidence of codesign work between buyers and suppliers. The reflexive effects of such work on respondent behaviour are, however, hard to predict. On the one hand, co-design will directly increase the organisation's dependence on suppliers, and thus may be resisted (see hypothesis 1 above). On the other hand, it increases the degree of asset specificity which has varying cost implications. Thus, buyer investment in specialised assets tends to increase transaction costs whilst supplier investment in customer-specific assets tends to lower transaction costs and increase satisfaction with the supplier (Artz, 1999). The same changes also increase switching costs and thus tend to increase loyalty towards existing suppliers (Ping, 1993; Heide and Weiss, 1995). Thus, on balance:

\section{H 3: The greater the incidence of co-designed products or services, the higher the degree of supplier empathy.}

\section{Co-operative strategic objectives}

Wagner et al. (2002) identify that cooperation between firms can only be achieved if partnering objectives are aligned with the strategic objectives of the organisations involved. This is also implied in Rebernick and Bradac's (2006) findings that an acknowledgement of interdependence and a long-term strategic interest to cooperate is critical to the success of outsourcing. Simatupang and Sridharan (2005), argue that to effectively moderate supply chain discontent, the chain members need to collaboratively design mutual strategic objectives. Svahn and Westerlund (2009), show that an organisation's purchasing strategies depend on the nature of their supply relationships (cooperative or adversarial). González-Benito (2007) and Baier et al. (2008) stress the importance of achieving alignment between the organisation's overall strategic objectives and those of the purchasing function. The choice of overall corporate strategies such as a costfocus or differentiation will have some effect on buyer-supplier interactions, and thus influence buyer attitudes and behaviour. Furthermore, the official, stated strategic purchasing plans and objectives employed by organisations form part of their internal culture and are also likely to have a similar influence (cf. Cousins and Spekman, 2003). If the organisation has incorporated the partial cooperation consensus into its strategic objectives, then this may affect the degree of supplier empathy, thus:

H4: Respondents in organisations with explicit partnership or supply chain cooperation objectives will display an enhanced degree of supplier empathy. 


\section{Support for long-term trading relationships}

Existing studies of the possible connections between the nature of trading relationships and the length of time they have persisted have generated a variety of often conflicting results. Ganesan (1994) argues that buyers were likely to have a long-term orientation with suppliers upon whom they were dependent. Claro $e t$ al. (2003) conclude that the length of the relationship had no impact on the willingness to engage in joint activities, while Cai and Yang (2008) suggest that the length of the relationship had no influence on buyers' acceptance of cooperative norms. Pillai and Sharma (2003) meanwhile suggest that longer-term relationships reduce buyer support for relational exchange but, in investigating JIT relationships, Buvik and Halskau (2001) conclude that if the amount of investment in the JIT arrangements is substantial, then the longer the relationship, the more buyers relax their hierarchical control. Finally, Johnston and Kristal (2008) argue that both buyers and suppliers displayed more cooperative behaviour if they expected the relationship to continue.

Thus the literature suggests that there may well be a connection between the length of a trading relationship and attitudes towards cooperation. However, the nature of that connection, and the direction of causation is unclear. With hindsight, this confusion is entirely predictable. Not only is it possible that increased supplier empathy may generate better relationships with suppliers, but also that better relationships might encourage increased levels of empathy, or both. It was beyond the scope of this study to remove all ambiguity, instead the focus is on the possible connection between empathy and the length of the relationship, hence:

\section{H 5: Buyers who report better long-term trading relationships will display a higher degree of supplier empathy.}

\section{The effects of enhanced supplier empathy}

One of the underlying assumptions of the partial cooperation consensus is that the avoidance of short-term, aggressive, competitive, pressure-based interactions with suppliers and the embrace of the longer-term, cooperative relational exchange approach will generate enhanced organisational performance. For example, Green and Lenard (1999) cited in Walker et al. (2002) report that cooperation can reduce costs by up to $30 \%$ and waste by $20 \%$. Other benefits such as reduced supplier search costs, easier management of the supplier interface and more stable prices have also been summarised by Vereecke and Muylle (2006) and Matopoulos et al. (2007). Stuart (1997) suggests that firms with strong trading alliances reported higher levels of productivity and quality than those reporting weak alliances. In addition, Leuthesser (2007) note that "relational behaviour is instrumental in influencing relationship quality". Thus suppliers who employ the relational approach tend to have more empathetic customers, more sales and better quality. The reverse 
may also be true, and part of that effect may take the form of a reduced incidence of problems with suppliers, hence:

\section{H 6: Respondents who display a high degree of supplier empathy will experience a lower incidence of problem suppliers.}

\section{Conceptual model}

Figure 1 shows our conceptual model and the hypothesised relationships between supplier empathy, dependence aversion, innovation focus, co-design incidence, cooperative objectives, length of trading relationship, and incidence of problem suppliers.

\section{Figure 1: Supplier Empathy Hypotheses}

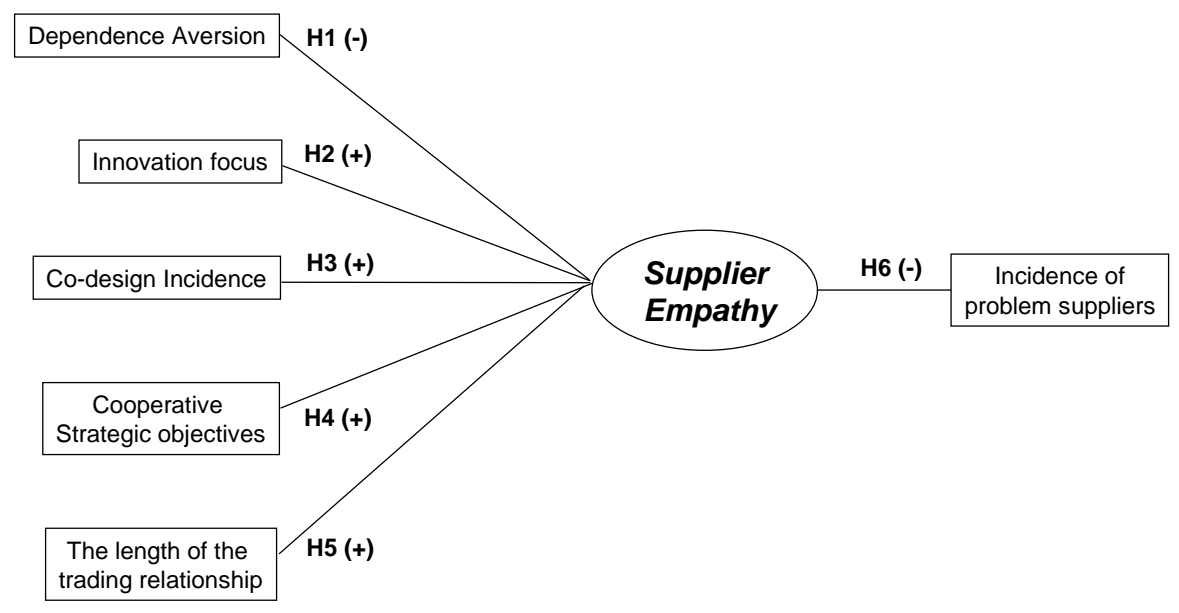

\section{Method}

\section{Study design}

It would have been possible to carry out a small-scale investigation of the perceptions and attitudes of matching pairs of trading buyers and suppliers, but since one of the main objectives of this work was to try to test for the presence of a possible consensus amongst buyers in general, the decision was taken to conduct a large-scale survey with buyers and their behaviours as the unit of analysis. The choice of survey 
allows a large sample size and thus gives increased confidence in the study findings (Sekaran, 2003). The survey consisted of twenty-one single item questions, two 9-item questions and space for additional comments (See Appendix 1 for relevant survey items).

\section{Measure development}

As noted earlier, the effects of social acceptability bias may be reduced if indirect questions are employed, consequently the respondents' degree of supplier empathy (and hence, implied support for the relational exchange perspective) was determined by asking them to rate two sets of questions. The first contained a selection of behaviours that are likely to be regarded as attractive (or unattractive) by suppliers (see questions 7 [a-i] in Appendix 1), and respondents were asked to comment on their likely usefulness in persuading suppliers to do what buyers wanted them to do. It was assumed that buyers who favour behaviours that suppliers are likely to regard as unattractive are failing to display supplier empathy, and thus are unlikely to be supportive of the partial consensus and relational exchange approach. The second set asked respondents to consider a variety of factors that might affect buyers and suppliers, and asked them to rate their significance in creating poor (or harmonious) working relationships (see questions 8 [a-i] in Appendix 1). In an effort to minimise the risk of consistency motif bias (Schmitt, 1994), some of the questions referred to buyer behaviours and some to those of suppliers. The buyer behaviours in the latter set of questions drew on the list of 'sources of supplier value' presented in Ramsay and Wagner (2009). Sources of supplier value are various buyer behaviours and characteristics that suppliers regard as beneficial or desirable. The underlying assumption was that, as mentioned earlier, buyers who tend to blame suppliers for poor relationships are failing to display supplier empathy and thus are unlikely to be supportive of the partial consensus and relational exchange approach.

The research design was intended to encourage a high response rate and therefore the number of questions was kept to a minimum. Whilst it was decided to use multiple items to measure supplier empathy, single-item measures were used for all other constructs. Single-item construct measures can be used for measuring both self-reported facts and psychological constructs. Measuring self-reported facts is a commonly accepted practice and in this study these relate to (H2) strategic objectives; (H3) incidence of co-design; and (H4) explicit partnership objectives. In addition, single-item measures were used for the control variables - company size, number of suppliers, and purchasing experience (See questions 4, 5, and 6 in appendix 1). Whilst it is less common to use single-item measures for psychological constructs, there is a good deal of support for their use in the applied psychology literature (Sackett and Larson, 1990; Ilgen et al. 1981). Scarpello and Campbell (1983), in assessing measures of job satisfaction, argue that a single-item measure of overall job satisfaction was preferable to a scale that is based on a sum of specific job facet satisfactions. Findings of Wanous et al. (1007), based on a meta-analysis of single-item and multi-item scales, bolster support for the use of single-item measures. They note that in many cases, the additional space required for multi-item construct measures is simply not practical and may damage response rates. In 
addition, they suggest that there may be issues of face validity with scales, particularly is respondents feel they are being asked questions that appear to be repetitious. In the current study, single items were used to measure perceptual constructs relating to (H1) supplier dependence aversion; (H5) support for long-term trading; and (H6) incidence of supplier problems.

A preliminary draft of the survey was pre-tested by three academics and six procurement managers. Feedback from this pilot resulted in the re-wording of several questions to minimise misinterpretation.

\section{Data collection}

The population frame from which the sample was drawn was the register of 55,000 members of the Chartered Institute of Purchasing and Supply. A simple random sample of $8.7 \%$ of this list was taken generating a list of 4700 potential respondents. This provided respondents from a range of sectors and industries with a variety of supply base sizes. A web-based approach was employed, based on the recommendations of Richman et al. (1999) for reducing social acceptability bias. Individuals were invited by e-mail to complete the survey online via a web link. A total of 421 useable responses were received, representing a response rate of $9 \%$ which is considered satisfactory for a number of reasons. Firstly, the absolute sample size of 421 exceeds all suggestions found in the literature: 100 (Hatcher, 1994), 100-200 (Velicer and Fava, 1998), 200 (Gorsuch, 1983), and 150-300 (Hutcheson and Sofroniou, 1999). Secondly, the subject-to-variable ratio of 23.4-to-1 exceeds the commonly used cut-off of 10-to-1 (Bryant and Yarnold, 1995). Thirdly, pointing to US election polling, Cook et al. (2000), note that the representativeness of samples is significantly more important than sample size and that this does not increase monotonically with increasing response rate (see also, Krosnick, 1999).

The demographic information of respondents is shown in table 2 . The majority of respondents work in private sector organizations. Nearly a quarter of respondents work in the public sector. $34.9 \%$ work in service industries, $28.8 \%$ in manufacturing, $8.7 \%$ in public administration or defence, and $8.2 \%$ in construction. The majority of respondents are employed in organizations with over 250 employees - nearly $70 \%$ had over 250 suppliers, with $46.3 \%$ over 1000 . Over three quarters of respondents have more than 10 years purchasing and supply management experience.

Table 2 - Demographic information

\begin{tabular}{|l|l|l|l|}
\hline & & No & Percent \% \\
\hline Sector & Public & 102 & 24.7 \\
\hline & Private & 302 & 72.1 \\
\hline & $3^{\text {rd }}$ & 9 & 2.2 \\
\hline & & & \\
\hline Industry & Agriculture, forestry, and fishing & 1 & .2 \\
\hline
\end{tabular}




\begin{tabular}{|c|c|c|c|}
\hline & Mining and quarrying & 1 & .2 \\
\hline & Manufacturing & 119 & 28.8 \\
\hline & Wholesale and retail trade & 30 & 7.3 \\
\hline & Electricity, gas and water supply & 14 & 3.4 \\
\hline & Construction & 34 & 8.2 \\
\hline & Accommodation and food services & 4 & 1.0 \\
\hline & Transportation and storage & 13 & 3.1 \\
\hline & Information and communication & 22 & 5.3 \\
\hline & Finance and insurance & 24 & 5.8 \\
\hline & Real estate & 1 & .2 \\
\hline & Professional services & 9 & 2.2 \\
\hline & Administrative and support services & 0 & 0.0 \\
\hline & Arts and entertainment & 3 & .7 \\
\hline & Other services & 52 & 12.6 \\
\hline & Public administration and defence & 36 & 8.7 \\
\hline & Education & 19 & 4.6 \\
\hline & Health and social work & 21 & 5.1 \\
\hline \multirow{7}{*}{$\begin{array}{l}\text { Number of } \\
\text { employees }\end{array}$} & Sole proprietor & 0 & 0 \\
\hline & $<10$ & 1 & 0.2 \\
\hline & $10-30$ & 8 & 1.9 \\
\hline & $31-50$ & 14 & 3.4 \\
\hline & $51-100$ & 17 & 4.1 \\
\hline & $101-250$ & 40 & 9.7 \\
\hline & $>250$ & 333 & 80.6 \\
\hline \multirow{7}{*}{$\begin{array}{l}\text { Number of } \\
\text { suppliers }\end{array}$} & $<50$ & 32 & 8.2 \\
\hline & $51-100$ & 21 & 5.4 \\
\hline & $101-250$ & 65 & 16.7 \\
\hline & $251-1000$ & 91 & 23.4 \\
\hline & $1001-5000$ & 113 & 29.3 \\
\hline & $5001-10,000$ & 39 & 10.1 \\
\hline & $>10,00$ & 27 & 6.9 \\
\hline \multirow{4}{*}{$\begin{array}{l}\text { Purchasing and } \\
\text { supply } \\
\text { management } \\
\text { experience (years) }\end{array}$} & $<2$ & 8 & 1.9 \\
\hline & $2-5$ & 25 & 6.1 \\
\hline & $6-10$ & 67 & 16.2 \\
\hline & $>10$ & 313 & 75.8 \\
\hline
\end{tabular}

\section{Preparation for analysis}

Data were entered in SPSS 14.0. T-tests compared early and late respondents to assess non-response bias. No significant differences were found. Missing value analysis (MVA) was used to assess missing data patterns. T-tests between missing and non-missing groups for each variable and an overall test of randomness indicate that missing data is "missing completely at random" (MCAR). Excluding missing values is the best choice, because the valid sample for statistical tests remains high (Sekaran, 2003). In checking for outliers, Mahalanobis distance testing indicated just eight respondents with standardised 
residuals $+/$ - three standard deviations from the predicted residual. Hair et al. (2006) argue that unless one can prove that the outlier is not representative of any observation in the population, it should not be deleted from analysis as the improvement in the results of multivariate analysis comes at the cost of generalisation. Therefore, all data were retained prior to further analysis.

Harman's conventional one-factor test was conducted to test for the presence of common method bias (Podsakoff and Organ, 1986; Podsakoff and Dalton, 1987). All 31 scale variables were entered into an exploratory principal components factor analysis (PCA) and principal axis factoring (PAF) and subjected to an oblique rotation (Direct Oblimin) to identify how many factors are required to account for variable variance. The presence of substantial common method variance may be shown if a single factor emerges from this analysis or the first factor accounts for the majority of covariance among the variable (Greene \& Organ, 1973; Aulakh\& Gencturk, 2000). Both PCA and PAF revealed the presence of 12 factors with eigenvalues $>1.0$ rather than a single factor. Of the $62 \%$ of variance explained by the 12 factors, only $11 \%$ was explained by the first factor, indicating that no general factor is present. These results appear to suggest that the risk of common method bias is minimal and is unlikely to confound interpretation of analysis. However, as Podsakoff et al (2003) observe, the fact that multiple factors emerge from the analysis: ' ...is not evidence that the measures are free of common method variance." (p. 889) [emphasis added]. They regard Harman's single factor test as inadequate. Given the emphasis in the current study on the role played by bias in this particular subject area, these warnings were heeded and further measures taken to test for the presence of social acceptability bias (see below).

Finally, it was important to ensure there were sufficient inter-correlations in the data matrix to justify the use of factor analysis for the supplier empathy construct. Factor analysis adequacy was assessed using the Kaiser-Meyer-Olkin (KMO) Measure of Sampling Adequacy and Bartlett's Test of Sphericity. The overall KMO statistic of 0.715 exceeds most minimum cut-offs marks $(.50, .60, .70, .80)$ suggested in the literature (Hair et al. 2006). Considering Bartlett's Test of Sphericity, the low significance $(<.000)$ disproves the null hypothesis that there are few significant relationships in the data. Taken together, the tests relating to non-response bias, outliers, and inter-correlations indicate the suitability of proceeding with factor analysis.

\section{Factor analysis}

18 items seeking to measure supplier empathy (see questions 7 and 8 ) were subjected to exploratory factor analysis (EFA) as the factor structure is determined by empirical data rather than theory (Velicer \& Jackson, 1990). The extraction method used in this research was Principal Components Analysis and the number of factors extracted was determined by the latent root criterion (Dunteman, 1989). For this data, initial eigenvalues suggested a solution of six factors which explains $58.9 \%$ of total variance. As expected, when orthogonal rotation was carried out, a number of items did not load clearly on a single factor, implying that supplier empathy factors are not independent. Therefore, the solution was subjected to an 
oblique rotation (Direct Oblimin) which produced an easily interpretable factor-loading matrix. To ensure practical significance, factor loadings \pm .40 were omitted (Hair et al. 2006). One item (excessive demands) of the 18 entered cross-loaded on two factors and was deleted from further analysis. A further one item (exclude suppliers from early knowledge of future business) was deleted during purification to improve scale reliability.

\section{Data analysis}

The data analysis is presented as follows. Firstly, results of factor analysis for the supplier empathy construct, including tests for reliability and validity are provided. Secondly, the extent to which practitioners support the partial consensus concerning the benefits of buyer-supplier cooperation is examined. Thirdly, hypotheses 1 to 5 relating to factors that may influence the degree of supplier empathy displayed by buyers are tested. Fourthly, the relationship between the presence of supplier empathy and the incidence of supplier problems is analysed. Finally, the extent of social acceptability bias present in the respondents' answers is tested for.

\section{Supplier empathy factor analysis}

Table 3 shows the final factor solution with details of factor loadings and alpha coefficients.

Table 3 Supplier Empathy Factor Solution

\begin{tabular}{|l|l|l|l|l|l|l|}
\hline \multicolumn{1}{|c|}{ Variable } & & & & & & \\
& & & & & & \\
& & & & & \\
\hline poor supplier communication skills & .562 & & & & & \\
\hline lack of concern for supplier needs & .692 & & & & & \\
\hline poor buyer communication skills & .765 & & & & & \\
\hline poor buyer planning performance & .758 & & & & & \\
\hline lack of buying power & & .609 & & & & \\
\hline supplier focus on other customers & & .777 & & & & \\
\hline extended supplier lead-time & & & .804 & & & \\
\hline delayed payment & & & .419 & & & \\
\hline higher price offer to suppliers & & & .722 & & & \\
\hline technical assistance to supplier & & & & .721 & & \\
\hline
\end{tabular}




\begin{tabular}{|l|l|l|l|l|l|l|}
\hline prompt payment & & & & .705 & & \\
\hline supplier involvement in business decisions & & & & .692 & & \\
\hline use of competitive pressure & & & & & .815 & \\
\hline threat of lost business & & & & & .706 & \\
\hline unreasonable supplier behaviour & & & & & & .752 \\
\hline supplier generated quality problems & & & & & & .621 \\
\hline
\end{tabular}

Given the fact that the research was not longitudinal (test-retest) and there is no alternative construct measure (parallel forms), assessment of reliability focuses on internal consistency (Flynn et al., 1990). The overall alpha for the supplier empathy construct is .605 which exceeds the cut-off point of .60 suggested by Nunally (1978) for exploratory research. The alphas for individual factors are relatively weak, ranging from .442 to .746 , suggesting further work in refining the supplier empathy measure may be required in the future. Moderate reliabilities and clear factor structure provide support for trait validity of the supplier empathy construct (Peter, 1981). However, this is not sufficient in assessing the extent to which a scale captures the latent construct (Churchill, 1979). Content validity cannot be determined statistically, but rather by experts with reference to experience and literature (Sekaran, 2003). In explicating the supplier empathy construct, a wide range of literature was drawn on and combined with quantitative data. The resulting scale appears to accurately reflect the construct, thus exhibiting good content validity. Construct validity measures the extent to which a scale is a good operational definition of a construct and can be split into two elements. Convergent validity is established when variables load on a single factor and correlate with other variables in their assigned factors (Bagozzi, 1981). Discriminate validity is indicated if the factors and variables are truly different for one another (Carman, 1990). The rules of variable convergence and discrimination hold good for this data. The factor analysis reveals that of the original 18 variables, 17 load on a single factor and only one further item was deleted during purification.

\section{Practitioner displays of supplier empathy}

The first research question was concerned with the extent to which buyer behaviour supports the relational exchange approach to buyer-supplier relationships - as indicated by the extent to which buyers exhibit supplier empathy. Table 4 provides descriptive data of supplier empathy scores for those who responded to the survey. The average degree of supplier empathy was .24 on a scale between -4 and +4 . Therefore, on the question of whether buyer behaviours and attitudes suggest support for the relational exchange perspective, the results are inconclusive. Respondents appear to neither strongly support nor reject the procooperation consensus.

Table 4. Overall Supplier Empathy: Descriptive Statistics 


\begin{tabular}{|l|l|l|l|l|l|}
\hline Variable & $\mathrm{N}$ & Minimum & Maximum & Mean & Std. Deviation \\
\hline $\begin{array}{l}\text { Degree of Supplier } \\
\text { Empathy }\end{array}$ & 413 & -1.675 & 1.625 & .24177 & .559320 \\
\hline
\end{tabular}

\section{Hypothesis 1: Dependence aversion}

The literature provided a number of studies suggesting that buyers who are averse to dependence on their suppliers are likely to be less supportive of the relational exchange perspective and therefore are likely to display lower levels of supplier empathy.

\section{H1: The higher the degree of supplier-dependence aversion, the lower will be the degree of supplier empathy.}

Attitudes towards supplier dependence were shown by responses to question 9. Correlation analysis was used to assess the extent to which levels of supplier-dependence aversion are negatively associated with levels of supplier empathy. Evidence was found for a negative relationship (-.107*) and this was significant to a 0.05 level. As buyers become increasingly averse to dependence on suppliers, they exhibit lower levels of supplier empathy. However, this relationship is relatively weak, and linear regression, with supplier dependence aversion as the independent variable and supplier empathy as the dependent variable, resulted in a model with little explanatory power (R.189; $\left.\mathrm{R}^{2} .04\right)$. As such, hypothesis 1 is partially supported in the form of a relatively weak but significant negative correlation between supplier dependence aversion and levels of supplier empathy.

\section{Hypothesis 2: Innovation focus}

In the literature review, it was argued that organisations that focus on innovation as their primary source of sustainable competitive advantage may favour the relational exchange perspective in order to reap the benefits of supplier innovations.

\section{H2: Respondents with strategic objectives focused on innovation will display higher levels of supplier empathy than those with other strategic foci.}

The primary strategic focus of respondent firms was recorded in question 10 of the survey. Of the 413 respondents to this question, $10.2 \%$ of the respondents stated that the primary focus of their organisation was innovation. Quality was the primary focus for $43.8 \%$ of respondents, $36.1 \%$ were most concerned with 
cost, whilst $8.8 \%$ were focused on speed of delivery. Table 5 shows the supplier empathy scores for those with a primary focus on innovation $(0.71)$ and those with other primary strategic foci $(0.19)$.

Table 5. The effects of strategic focus on Supplier Empathy

\begin{tabular}{|l|l|l|l|l|l|}
\hline \multicolumn{2}{|l|}{} & $\mathrm{N}$ & Mean & Std. Deviation & Std. Error \\
\hline Innovation focus & 42 & .70714 & .536284 & .082750 \\
\hline Other strategic foci & 371 & .18908 & .537693 & .027916 \\
\hline Total & 413 & .24177 & .559320 & .027522 \\
\hline Model & Fixed Effects & & & .537552 & .026451 \\
\hline & Random Effects & & & & .327482 \\
\hline
\end{tabular}

Degree of Supplier Empathy

Analysis of variance (ANOVA) was used to examine the hypothesis that respondents with strategic objectives focused on innovation will display higher levels of supplier empathy compared with other strategic foci (Table 6). ANOVA compares the means for different groups - in this case, innovation focus versus other primary foci - and assess the extent to which differences are significant. Small significance values (<.05) indicate group differences. In this case, the significance of .000 indicates that supplier empathy levels for respondents with a primary focus on innovation are significantly higher than those for respondents with other strategic foci. Hypothesis 2 is therefore supported.

Table 6. Strategic focus on Supplier Empathy: ANOVA results

\begin{tabular}{|l|l|l|l|l|l|}
\hline & Sum of Squares & Df & Mean Square & F & Sig. \\
\hline Between Groups & 10.126 & 1 & 10.126 & 35.042 & .000 \\
\hline Within Groups & 118.764 & 411 & .289 & & \\
\hline Total & 128.890 & 412 & & & \\
\hline
\end{tabular}

Degree of Supplier Empathy

\section{Hypothesis 3: Co-design}

The literature review indicated that, on balance, increased levels of co-design will be positively correlated with supplier empathy and the norms associated with relational exchange.

H 3: The greater the incidence of co-designed products or services, the higher the degree of supplier empathy. 
The extent to which respondent organisations engage in joint design with suppliers was examined using question 11. Correlation analysis was employed to assess the association between co-design incidence and supplier empathy. Evidence was found for a positive relationship between the use of co-design and supplier empathy $\left(.127^{*}\right)$ and this was significant to a 0.1 level. As the level of reported joint design work increases, there is a small increase in levels of supplier empathy. In addition to correlation analysis, linear regression was undertaken to examine the extent to which the use of joint design predicts levels of supplier empathy. The resulting model had limited explanatory power (R.192; $\left.\mathrm{R}^{2} .04\right)$. Hypothesis 3 is therefore partially supported in the form of a relatively weak but significant positive relationship with joint design efforts and levels of supplier empathy.

\section{Hypothesis 4: Co-operative strategic objectives}

A number of studies suggest that respondents in organisations with explicit co-operative objectives are likely to be more supportive of norms associated with the relational exchange perspective.

\section{H4: Respondents in organisations with explicit partnership or supply chain cooperation objectives will display an enhanced degree of supplier empathy.}

The existence of formally stated objectives concerning the need to form partnerships or to be more cooperative with suppliers was measured in question $12.62 \%$ of the respondents reported that they had a formally stated objective for strategic supplier partnerships. These respondents had average supplier empathy scores of 0.347 compared with the average of 0.07 for respondents with no formally stated cooperation objectives. Analysis of variance (ANOVA) was used to compare the means for these two groups and assess the extent to which differences are significant (Table 7). In this case, the significance of .000 indicates that supplier empathy levels for respondents with formally stated co-operation objectives are significantly higher than those without such stated objectives. Thus, hypothesis 4 is supported by the data.

Table 7. Partnership/Co-operation objectives affect on supplier empathy: ANOVA results

\begin{tabular}{|l|l|l|l|l|l|}
\hline & Sum of Squares & Df & Mean Square & F & Sig. \\
\hline Between Groups & 7.360 & 1 & 7.360 & 24.793 & .000 \\
\hline Within Groups & 121.412 & 409 & .297 & & \\
\hline Total & 128.772 & 410 & & & \\
\hline
\end{tabular}

Degree of Supplier Empathy 


\section{Hypothesis 5: Support for long-term trading relationships}

The literature suggests that there may be a positive relationship between organisations who favour longterm interactions with suppliers and their support for the relational exchange perspective.

\section{H 5: Buyers who report better long-term trading relationships will display a higher degree of supplier empathy.}

Support for the view that interactions with long-term suppliers are significantly better than those with shortterm suppliers was examined using question 13. In examining hypothesis 5, correlation analysis indicated a strong, positive, and significant relationship (.364**) between supplier empathy and the view that longterm trading partners generate significantly better relations than short-term trading relations. The results indicated that respondents who reported that longer-term relations were more harmonious than shorter-term relations display higher levels of supplier empathy. Further testing of the hypothesis used linear regression analysis to examine the extent to which support for long-term trading predicted levels of supplier empathy. The regression model explains $52.2 \%$ of variance in supplier empathy (Table 8). Considering the power of the regression model, a comparison of the regression sum of squares (64.25) and the residual sum of squares (55.53) indicates that the model accounts for significant amount of variation in the dependent variable. Residuals for the data set range from -1.52 to +1.67 . The fact that these residuals follow a normal distribution indicates that the model is appropriate for the data. Hypothesis 5 is therefore supported by the data.

Table 8. Regression model showing effect of long-term trading support on supplier empathy

\begin{tabular}{|l|l|r|r|r|r|}
\hline Model & $\mathrm{R}$ & R Square & $\begin{array}{c}\text { Adjusted R } \\
\text { Square }\end{array}$ & $\begin{array}{c}\text { Std. Error of } \\
\text { the Estimate }\end{array}$ & Durbin-Watson \\
\hline 1 & $.167(\mathrm{a})$ & .028 & .020 & .552108 & \\
\hline 2 & $.732(\mathrm{~b})$ & .536 & .532 & .381764 & 1.837 \\
\hline
\end{tabular}

a Predictors: (Constant), The number of years you have been involved in purchasing and dealing directly with suppliers, The total number of suppliers your organisation deal with (approx), The number of employees across your whole organisation

b Predictors: (Constant), The number of years you have been involved in purchasing and dealing directly with suppliers, The total number of suppliers your organisation deal with (approx), The number of employees across your whole organisation, "Our personal interactions with long-term suppliers are significantly better than those with shortterm suppliers"

\section{Hypothesis 6: The effect of supplier empathy on trading relations}

Within the literature, work of a number of authors can be interpreted as suggesting that support for the relational exchange perspective, as evidenced by enhanced levels of supplier empathy, is likely to result in a reduction in the incidence of supplier problems. 


\section{H 6: Respondents who display a high degree of Supplier Empathy will experience a lower incidence of problem suppliers.}

Respondent perceptions relating to the level of supplier problems were examined using question 14 . Of the 409 respondents answering this question, $33.4 \%$ reported that ten percent of their suppliers routinely cause them problems, $28.8 \%$ put the figure at twenty percent, and $22.3 \%$ at thirty percent. The remaining $15.1 \%$ was spread between 'none', forty, fifty, sixty, seventy, eighty, and ninety percent. In testing hypothesis 6 , the correlation between supplier empathy and problem suppliers was firstly examined using correlation analysis. Respondents who displayed a high level of supplier empathy did indeed report a lower incidence of problem suppliers. This positive correlation is both strong and highly significant (-.572***) and is clearly illustrated by the scatter plot in figure 2 below.

Figure 2: Scatter plot showing relationship between supplier empathy and supplier problems

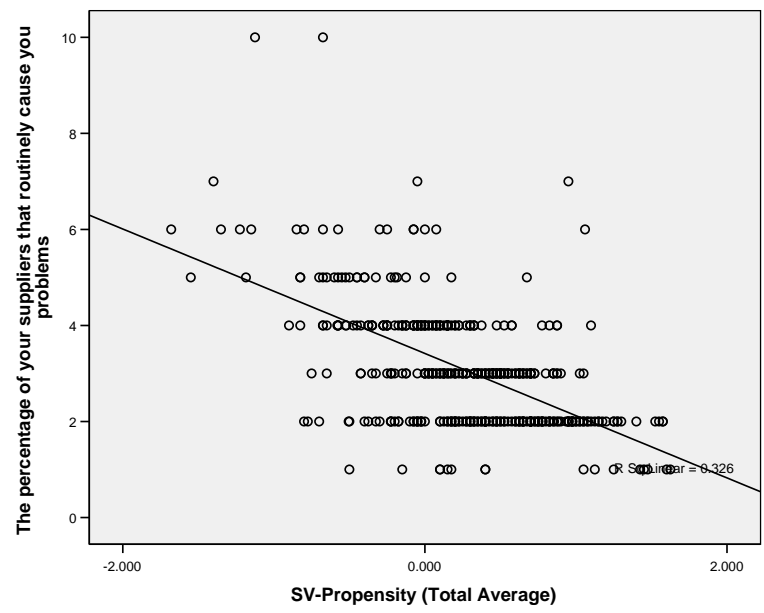

Further testing of the hypothesis used linear regression analysis to examine the extent to which levels of supplier empathy predict reported supplier problems. The regression model explains $31.9 \%$ of variance in problem supplier incidence (Table 9). Considering the power of the regression model, a comparison of the regression sum of squares (193.85) and the residual sum of squares (400.33) indicates that the model accounts for significant amount of variation in the dependent variable. Residuals for the data set range from -2.87 to +5.94 . The fact that these residuals follow a normal distribution indicates that the model is appropriate for the data. Hypothesis 6 is therefore supported by the data.

Table 9. Regression model showing effect of supplier empathy on supplier problems 


\begin{tabular}{|l|l|r|r|r|r|}
\hline Model & $\mathrm{R}$ & \multicolumn{1}{|c|}{ R Square } & $\begin{array}{c}\text { Adjusted R } \\
\text { Square }\end{array}$ & $\begin{array}{c}\text { Std. Error of } \\
\text { the Estimate }\end{array}$ & Durbin-Watson \\
\hline 1 & $.225(\mathrm{a})$ & .051 & .043 & 1.215 & \\
\hline 2 & $.571(\mathrm{~b})$ & .326 & .319 & 1.025 & 1.962 \\
\hline
\end{tabular}

a Predictors: (Constant), The number of years you have been involved in purchasing and dealing directly with suppliers, The total number of suppliers your organisation deal with (approx), The number of employees across your whole organisation

b Predictors: (Constant), The number of years you have been involved in purchasing and dealing directly with suppliers, The total number of suppliers your organisation deal with (approx), The number of employees across your whole organisation, SV-Propensity (Total Average)

c Dependent Variable: The percentage of your suppliers that routinely cause you problems

It is worth noting that the statistical power of the regression model is partly determined by sample size (Hair et al., 2006). Very small samples (<20) often only allow the use of simple regression with one independent variable, with only very strong relationships detected with certainty. There are also problems with very large samples (>1000) due to over-sensitivity to statistical tests, often indicating the statistical significance of almost any relationship. Detecting significant $R^{2}$ is also affected by the number of independent variables and the significance level chosen. For this research, when using the 16 items in the Supplier Empathy scale as independent variables and specifying a .01 significance level, the sample of 413 will detect $R^{2}$ values of around $0.06(6 \%)$ and greater. As such, the large sample and small set of items gives a high degree of confidence in the statistical power of the analysis. Sample size also affects the extent to which results can be generalised. The sample becomes more representative of the population as its size increases. (Hair et al., 2006) suggest that, assuming a representative sample, the ratio of observations to independent variables should always be greater than 5-to-1 and ideally between 15 and 20-to-1. In this research, the ratio of observations to independent variables is 22.94-to-1.

\section{Testing for social acceptability bias}

As discussed in the literature review, where a well established consensus exists social acceptability bias is likely to distort the responses given by individuals, moreover the standard one-factor test is incapable of unequivocally establishing the absence of common method variance. Consequently efforts were made to avoid the likelihood of social acceptability bias through the design of questions (indirect) and the method of data collection (web-based). An attempt was also made to test for the presence of this particular common method bias by comparing the responses to different items making up the supplier empathy scale. Items in question 7 asked the respondents to comment upon their own behaviour towards suppliers and were thus more direct in nature. Items in question 8 focused on equivalent behaviours towards suppliers that respondents believe competitors use and were thus more indirect in nature. Asking the respondents to advise how they thought their competitors would behave towards suppliers and comparing the results with their reports of their own behaviour should constitute a test for the presence of this bias. This particular form of indirect questioning has been tested and found effective in reducing the complications of social acceptability bias (Fisher, 1993). Paradoxically however, if precisely the same set of questions about buyer 
behaviours were employed, it would also generate a significant risk of a variety of other forms of common method bias such as item context effects (Wainer \& Kiely, 1987), measurement context effects (Podsakoff et al., 2003), and particularly 'consistency motif' in which the respondents try to produce replies consistent with their replies to other questions (Johns, 1994). In order to avoid these problems a different set of questions was thus employed that was intended to identify the extent to which the respondents believed their competitors would tend to blame their suppliers rather than themselves for problems in trading relationships.

The mean average for 'direct' items measuring supplier empathy was 0.47 . However, the mean average for equivalent 'indirect' items measuring supplier empathy was 0.01 . To examine the extent to which social acceptability bias existed in the data, a paired-sample t-test was carried out. This procedure compares the means of two variables that represent the same group - in our case supplier empathy when measured directly and indirectly. These results are extremely significant $(<0.05)$ and suggest that when asked questions in a more indirect manner, respondents display attitudes that are less supportive of norms associated with supplier empathy and the relational exchange perspective. Therefore, as predicted, evidence for the presence of social acceptability bias in responses was found.

\section{Discussion}

Given the longevity of the partial buyer-supplier cooperation consensus, one might have expected to discover a high degree of supplier empathy and generalised support for the relational exchange perspective. In this context, this suggests that the "middle-range" responses are open to various interpretations. On the one hand, very large organisations of the kind many of the respondents work for might be expected to possess high levels of power, and hence enjoy a sharply reduced need to display empathy with their suppliers. Therefore one might argue that although relatively low, the overall incidence of empathy is predictable. On the other hand, the staff in these very large organisations may be more highly qualified than their equivalents in smaller companies (Belfield, 1999) and thus potentially exposed to the academic literature. In addition, as members of the Chartered Institute of Purchasing and Supply, many respondents will have been exposed to the partial cooperation consensus in the Institute's house journal: Supply Management. For these reasons, it can be argued that the relatively low level of supplier empathy is somewhat surprising. Furthermore, there are strong grounds for believing that social acceptability bias is present in the this study's responses, and thus respondents' reported degree of supplier empathy may well have been artificially high; respondents may actually have possessed a lower degree of empathy than they reported. Hence, on balance, the findings may indicate not so much a "relatively low" as a "very low" degree of supplier empathy.

The results of the test for the presence of social acceptability bias suggest that academics in the Operations and Supply Management field might benefit from raising their awareness of the possibility of social acceptability bias being present in their empirical findings, and taking appropriate steps to identify 
and deal with it in their research designs. Although this paper makes very limited comment on the validity or usefulness or the partial consensus concerning the benefits of cooperation, its findings on the presence of social acceptability bias do provide a warning of the potential risks inherent in designing research work in subject areas where a consensus exists. Moreover, logic suggests that the number of such topics may be quite large. In the Purchasing \& Supply Management area for example, these might include: supply base rationalisation is beneficial; enhanced buyer-supplier transparency improves trading relationships; ecommerce improves performance and so on.

The analysis has successfully identified several factors that may influence respondent attitudes towards supplier empathy. The variables relating to aversion to supplier-dependence, a strategic focus on innovation, incidence of co-design work, explicit partnership objectives, and length of trading relationship were shown to be related to the respondents' levels of supplier empathy. Several of these variables are amenable to manipulation by management. Thus organisations wishing to improve their level of supplier empathy might promote staff training that undermined aversion to becoming dependent upon suppliers and emphasized the benefits of the relational exchange approach. They might also introduce explicit cooperation or partnership objectives and encourage the incidence of co-design efforts.

The finding that an enhanced awareness and response to supplier needs, wants and preferences is associated with a reduction in numbers of problem suppliers, and thus one might surmise, improved trading performance, appears to support the argument underlying the partial consensus that treating suppliers well is a desirable strategy to adopt. Given the nature of the sample, it is clear that even very large organizations that currently dominate their supply chains, can benefit significantly from higher levels of supplier empathy. Such organisations may currently be missing an opportunity to improve purchasing performance and overall competitiveness by ignoring the value of supplier empathy.

\section{Conclusions}

Referring back to the main objectives of this study one may conclude that, in very large companies at least, there is indeed a significant mismatch between the partial consensus concerning the desirability of buyersupplier cooperation and the attitudes and behaviours of buyers. Curiously this finding was accompanied by the fact that the respondents who displayed more supplier empathy reported better long-term trading interactions. This might appear to be self-evident, since it would have been extremely surprising to discover that suppliers whose interests and needs were addressed more fully, responded by generating more problems for their more empathic customers. There is no suggestion in the relevant literatures that the benefits of cooperative buyer-supplier interactions are limited to small and medium sized companies. Hence one may conclude that the very large company sector would profit from appreciating that, regardless of the level of power they possess within their various supply chains, the implications of the partial consensus applies to them also. 


\section{Research limitations and future research opportunities}

As with all research, there are limitations to the study. The decision to try to avoid the effects of social acceptability bias was taken quite late in the research design process, and restricted primarily to the design of the questions relating to the supplier empathy construct. With the benefit of hindsight, it would have been desirable to apply the technique of devising indirect questions about pertinent buyer behaviours or practices to all of the other key questions. One of other significant shortcomings of this study is the nature of the sample. In common with the majority of empirical work in the Operations and Supply Management field it was skewed towards very large companies. Since small companies do not have the luxury of using very large expenditure volumes to influence supplier behaviour, it is possible that a repeat of the same exercise with smaller companies would generate very different findings. Moreover, it might be useful to undertake a qualitative study to try to obtain richer detail about buyers' attitudes to the partial cooperation consensus.

The relational exchange analysis of buyer-supplier relationships also suffers from one serious shortcoming; it is incomplete. Cox et al. (2003 and 2005) powerfully and convincingly argue that a better understanding of buyer-supplier relationships requires consideration of more than simply what they call the

"way of working" - namely arms-length or collaborative relationships. It must also consider the distribution of the benefits or "surplus value" generated by the exchange. They develop an analytical approach using both dimensions. Relational exchange theory, in common with many other relationship treatments, makes no mention of the distribution of benefits or surplus value between the trading parties. Future research in this subject area would clearly benefit from the incorporation of the distribution of surplus value into the research design.

\section{References}

Allred, K. (2000), "Distinguishing best and strategic practices: A framework for managing the dilemma between creating and claiming value", Negotiation Journal, Vol. 16 Iss. 4, pp. 387-397

Armascott, R., Hosseini., J., Morris, S. and Rehbein, K. (1991), “An empirical comparison of direct questioning, scenario and randomized response methods for obtaining sensitive business information", Decision Sciences, Vol. 22 No. 5, pp. 1073-1090

Artz, K. (1999), "Buyer-supplier performance: the role of asset specificity reciprocal investments and relational exchange", British Journal of Management, Vol. 10, pp. 113-126

Attridge, M., Berscheid, E. and Sprecher, S. (1998), "Dependency and insecurity in romantic relationships: development and validation of two companion scales", Personal Relationships, Vol. 5 pp. 31-58

Aulakh, P. S. and Gencturk, E. F. (2000), “International principal-agent relationships: control, governance and performance, Industrial Marketing Management, Vol. 29, pp. 521538. 
Bagozzi, R. O. (1981), “Attitudes, intentions, and behavior: a test of some key hypothesis", Journal of Personality and Social Psychology, Vol. 41, pp. 607-627.

Baier, C., Hartmann, E. and Moser, R. (2008), "Strategic alignment and purchasing efficiency: An exploratory analysis of their impact on financial performance", Journal of Supply Chain Management, Vol. 44 No.4, pp. 36-51

Belfield, C. (1999), "The Behaviour of graduates in the SME labour Market: evidence and perceptions", Small Business Economics, Vol. 12 No. 3, pp. 249-59

Bensao, M. (1999), "Portfolios of buyer-supplier relationships", Sloan Management Review, Summer, pp. $35-44$

Berscheid, E. and Fei, J. (1977), "Romantic life and sexual jealousy”, in Clanton, G. and Smith, L., (Eds.), Jealousy, Prentice-Hall. Englewood Cliffs, NJ USA,

Bolton, M., Malmrose, R. and Ouchi, W. (1994), "The organization of innovation in the United States and Japan: Neo-classical and relational contracting”, Journal of Management Studies, Vol. 31 No. 5, September, pp. 653-679

Boshier, R. (1990), "Socio-psychological factors in electronic networking", International Journal of Lifelong Education, Vol. 9 No. 1, pp. 49-64.

Brown, J., Dev, C. and Lee, D-J. (2000), "Managing marketing channel opportunism: The efficacy of alternative governance mechanisms", Journal of Marketing, Vol. 64, April, pp.51-65

Bryant, F.B. and Yarnold, P.R. (1995), "Principal components analysis and exploratory and confirmatory factor analysis", In Grimm, L.G and Yarnold, P.R (Eds), Reading and understanding multivariate analysis, American Psychological Association Books: Washington, pp. 99-136

Buvik, A. and Halskau, Ø. (2001), "Relationship duration and buyer influence in just-in-time relationships", European Journal of Purchasing and Supply Management, Vol. 7, pp. 111-119

Cai, S. and Yang, Z. (2008), “ Development of cooperative norms in the buyer-supplier relationship: The Chinese experience", Journal of Supply Chain Management, Vol. 44 No. 1 pp. 55-70

Caldwell, N., Walker, H.., Harland, C., Knight, L., Zheng, J. and Wakeley, T. (2005), "Promoting competitive markets: The role of public procurement", Journal of Purchasing and Supply Management, Vol. 11 No. 5-6, pp. 242-251

Carman, J. M. (1990), "Consumer Perceptions of service quality: an assessment of the SERVQUAL dimensions", Journal of Retailing, Vol. 66, pp. 33-55.

Carr, A., Hale, K., Hartlet, J. and Ross, A. (2008), "Supplier dependence: impact on suppliers' participation and performance", International Journal of Operations and Production Management, Vol. 28 No. 9, pp. 899-916

Churchill, G. A. (1979), “A paradigm for developing better measures of marketing constructs”, Journal of Marketing Research, Vol. 16, pp. 64-73.

Claro, D., Hagelaar, G. and Omta, O. (2003), "The determinants of relational governance and performance: How to manage business relationships?", Industrial Marketing Management, Vol. 32, pp. 703-716

Claro, D., Claro, P. and Hagelaar, G. (2006), "Coordinating collaborative joint efforts with suppliers: the effects of trust, transaction specific investment and information network in the Dutch flower industry", Supply Chain Management: An International Journal, Vol. 11 No. 3, pp. 216-224

Cook, C., Heath, F. and Thompson, R.L. (2000), "A meta analysis of response rates in web -or Internetbased surveys", Educational and Psychological Measurement, Vol. 60, pp. 821- 836

Cordon, C. and Vollmann, T. (2005), "Who' s the fairest of them all?", CPO Agenda, Vol. 1 No 3, pp. 2428 
Cousins, P. and Spekman. R. (2003), "Strategic supply and the management of inter- and intraorganisational relationships", Journal of Purchasing and Supply Management, Vol. 9 No. 1, pp 1929

Cox, A., Lonsdale, C., Watson, G. and Wu, Y. (2005), "Supplier relationship management as an investment: evidence from a UK study", Journal of General Management, Vol. 30 No. 4, Summer, pp. $27-42$

Cox, A., Lonsdale, C., Watson, G. and Qiao, H. (2003), "Supplier relationship management: a framework for understanding managerial capacity and constraints", European Business Journal, 3rd Quarter, Vol. 15 No. 3, pp. 135-145

Croom, S. and Brandon-Jones, A. (2007), "Progress on e-procurement: experiences from implementation in the UK public sector". Journal of Purchasing and Supply Management, Vol. 13 No. 4, pp. 294-303

Da Silveira, G. and Arkader, R. (2007), "The direct and mediated relationships between supply chain coordination investments and delivery performance", International Journal of Operations and Production Management, Vol. 27 No 2, pp. 140-158

Davis, P. (2007), "The effectiveness of relational contracting in a temporary public organization: Intensive collaboration between an English local authority and private contractors", Public Administration, Vol. 85 No. 2, pp. 383-404

Davilla, J. and Bradbury, T. (2001), "Attachment insecurity and the distinction between unhappy spouses who do and do not divorce", Journal of Family Psychology, Vol. 15 No. 3, pp. 371-393

Dunteman, G. H. (1989), "Principal components analysis", Quantitative Applications in Social Sciences Series. Thousand Oaks, CA: Sage Publications,

Dyer, J., Cho, D. and Chu, W. (1998), "Strategic Supplier Segmentation: the next "best practice" in supply chain management", California Management Review, Vol. 40 No. 2, Winter, pp. 57-77

Emberson, C. and Storey, J. (2006), "Buyer-supplier collaborative relationships: beyond the normative accounts", Journal of Purchasing and Supply Management, Vol. 12 No. 5, pp 236-245

Fink, R., Edelman. and Hatten, K. (2007), “Supplier performance improvements in relational exchanges", Journal of Business and Industrial Marketing, Vol. 22 No. 1, pp. 29-40

Fisher, R. (1993), "Social desirability bias and the validity of indirect questioning", Journal of Consumer Research, Vol. 20, September, pp. 303-315

Fisher, R. and Tellis, G. (1998), "Removing social desirability bias with indirect questioning: is the cure worse than the disease?", Advances in Consumer Research, Vol. 25, pp. 563-567

Flynn, B. B., Sakakibara, S., Schroeder, R. G., Bates, K. A. and Flynn, J. E. (1990), Empirical research methods in operations management, Journal of Operations Management, Vol. 9, pp.250-284.

Ford, D. (Ed.), (1997), “An Interaction Approach”, in Understanding Business Markets, London, Dryden Press

Frolich, M. T. and Westbrook, R. (2001), "Arcs of integration: an international study of supply chain strategies", Journal of Operations Management, Vol. 19 No. 2, pp. 185-200

Galbraith, J. (1977), “The Age of Uncertainty”, Houghton Mifflin, Boston

Ganesan, S. (1994), "Determinants of long-term orientation in buyer-seller relationships", Journal of Marketing, Vol. 58, April, pp. 1-19.

Gil, N. (2008), "Developing cooperative project client-supplier relationships: How much to expect from relational contracts?", California Management Review, Vol. 51 No .2, Winter, pp. 144-169

Giunipero, L. and Hooker, R. (2008), “A decade of SCM literature: Past, present and future implications”, Journal of Supply Chain Management, Vol. 44 No. 4, pp. 66-86 
Gonzalez-Benito, J. and Spring, M. (2000), "JIT purchasing in the Spanish auto components industryimplementation patterns and perceived benefits", International Journal of Operations and Production Management, Vol. 20, No. 9, pp. 1038-1061

Gorsuch, R. L. (1983), “Factor Analysis”, Lawrence Erlbaum, Hillside, NJ

Green, S., Lenard, D. (1999), "Organising the project procurement process", in Rowlinson S, P. McDermott (Eds), Procurement Systems: A Guide to Best Practice in Construction, E\&FN Spon, London, pp. 57-82

Greene, C. N. and Organ, D.W. (1973), "An evaluation of causal models linking the received role with job satisfaction", Administrative Science Quarterly, Vol. 18 No. 1, pp. 95-103.

Gundlach, G. T., Achrol R. S. and Mentzer J. T. (1995), "The Structure of Commitment in Exchange", Journal of Marketing, Vol. 59, January, pp. 78-92

Gupta, Y.P. (1990), “A feasibility study of JIT purchasing implementation in a manufacturing facility", International Journal of Operations and Production Management, Vol. No. 1, pp. 31-41

Hair, J. F. Jr., Anderson, R.E., Tatham, R.L. and Black, W.C. (2006), “Multivariate Analysis”, 6th Edition, Prentice-Hall, London

Hancock, J. and Oates, S. (2001), "Minding other people's business: perspectives on outsourcing at Bradford and Bingley", Supply Chain Management: An International Journal, Vol. 6 No. 2, pp. 5860

Hatcher, L. (1994), “A step-by-step approach to using the SAS system for factor analysis and structural equation modeling", SAS Institute, Cary, NC

Heide, J. (1994) "Interorganizational governance in marketing channels", Journal of Marketing, Vol. 58, pp.71-85

Heide, J. and John, G. (1992). "Do norms matter in marketing relationships?”, Journal of Marketing, Vol. 56, pp. 32-44.

Heide, J. and John, G. (1990), "Alliances in industrial purchasing: the determinants of joint action in buyer-supplier relationships", Journal of Marketing Research, Vol. 27 No. 1, pp. 24-36

Heide, J. and Weiss, A. (1995), "Vendor consideration and switching behaviour for buyers in hightechnology markets", Journal of Marketing, Vol. 59 No. 3, pp. 30-43

Holm, D., Eriksson, K. and Johanson, J. (1996), "Business networks and cooperation in international business relationships", Journal of International Business Studies, pp. 1033-1053

Howard, M., Lewis, M., Miemczyk, J. and Brandon-Jones, A. (2007) "Implementing Supply Practice at Bridgend Engine Plant. The influence of institutional and strategic choice perspectives", International Journal of Operations and Production Management. Vol. 27 No. 7, pp. 754-776

Hughes, J. and Weiss, J. (2007), "Getting closer to key suppliers", CPO Agenda, Spring, pp. 19-25

Hutcheson, G. and Sofroniou, N. (1999), "The multivariate social scientist: Introductory statistics using generalized linear models", Sage Publications. Thousand Oaks, CA

Ilgen, D., Nebeker, D. and Pritchard, R., (1981), “Expectancy theory measures: An empirical comparison in an experimental simulation", Organizational Behavior and Human Performance, Vol. 28, pp. 189-223.

Jeffries, F. and Reed, R. (2000), "Trust and adaptation in relational contracting", Academy of Management Review, Vol. 25 No 4, pp. 873-882

Johns, G. (1994), "How often were you absent-A review of the use of self-reported absence data", Journal of Applied Psychology, Vol. 79, pp. 574-591.

Johnston, D. and Kristal, M. (2008), "The climate for co-operation: buyer-supplier beliefs and behaviour", International Journal of Operations and Production Management; Vol. 28 No. 9, pp. 875-898 
Jonsson, P. and Zineldin, M. (2003), “Achieving high satisfaction in supplier-dealer working relationships”, Supply Chain Management, Vol. 8 No. 3, pp. 224-240

Joshi, A. and Stump, R. (1999), "Determinants of commitment and opportunism: Integrating and extending insights from transaction cost analysis and relational exchange theory", Canadian Journal of Administrative Sciences, Vol. 16 No. 4, pp. 334-352

Kannan, V. and Choon Tan, K. (2004), "Supplier alliances: differences in attitudes to supplier and quality management of adopters and non-adopters", Supply Chain Management: An International Journal, Vol. 9 No. 4, pp. $279-286$

Kelman, H. C. (1958), "Compliance, identification, and internalization three process of attitude change", Journal of Conflict Resolution, Vol. 2 No. 1, pp. 51-60.

Kijkuit, B. and van den Ende, J. (2007), "The organizational life of an idea: Integrating social network, creativity and decision-making perspectives", Journal of Management Studies, Vol. 44 No. 6, September, pp. 853-862

King, M. and Bruner, G. (2000), "Social desirability bias: a neglected aspect of validity testing", Psychology and Marketing, Vol. 17 No. 2, pp. 79-103

Knight, D., Pearce, C., Smith, K., Olian, J., Sims, H. and Smith, K., (1999), "Top management team diversity, group process and strategic consensus", Strategic Management Journal, Vol. 20, pp. 445465

Krosnik, J. (1999), “Survey Research”, Annual Review of Psychology, Vol50, pp. 537-567.

Kumutasawamy, M., Rahman, M., and Phng, S. (2005), "Reconstructing cultures for relational contracting", Journal of Construction Engineering and Management, Vol. 131 No. 10, October, pp. $1065-1075$

Larson, A. (1992),"Network dyads in entrepreneurial settings: A study of the governance of exchange relationships", Administrative Science Quarterly, Vol. 37, pp. 76-104

Larson, P., Carr, P. and Dhariwal, K. (2005), "SCM involving small versus large suppliers: relational exchange and electronic communication media", Journal of Supply Chain Management, Vol. 41 No.1 pp. 18-36

Lau, H. and Lau, A., (1994), "Coordinating two suppliers with offsetting lead time and price performance", Journal of Operations Management, Vol. 11, pp. 327-337.

Lewicki, R., Barry, B., Saunders, D. and Minton, J. (2006), “Negotiation”, New York: McGraw-Hill

Leuthesser, L. (1997), "Supplier relational behaviour: An empirical assessment”, Industrial Marketing Management, Vol. 26, pp. 245-254

Lian, P. and Laing, A. (2004), "Public sector purchasing of health services: A comparison with private sector purchasing", Journal of Purchasing and Supply Management, Vol. 10 No. 6, pp 247-256

Liu, Y., Luo, Y. and Liu, T. (2009), "Governing buyer-supplier relationships through transactional and relational mechanisms: Evidence from China", Journal of Operations Management, Vol. 7 No. 4 , August, pp. 294-309

Lonsdale, C. and Watson, G. (2005), "The internal client relationship, demand management and value for money: A conceptual model", Journal of Purchasing and Supply Management, Vol.1 No. 1, pp. $159-171$

Macbeth, D. (2002), "Emergent strategy in managing cooperative supply chain change", International Journal of Operations and Production Management, Vol. 22 No. 7, pp. 728-740

Macneil, I. (1980), “The New Social Contract”, New Haven, Yale University Press 
Matopoulos, A., Vlachopoulou, M. and Manthou, V. (2007), “A conceptual framework for supply chain collaboration: empirical evidence from the agri-food industry", Supply Chain Management: An International Journal, Vol. 12/13, pp. 177-186

Mishra, A. and Shah, R. (2009), "In union lies strength: collaborative competence in new product development and its performance effects", Journal of Operations Management, Vol. 27 No 4, pp.324-338

Mollering, G. (2003), “A typology of supplier relations: from determinism to pluralism in inter-firm empirical research", Journal of Purchasing and Supply Management, Vol. 9, pp. 31-41

Moschandreas, M. (1997), "The role of opportunism in transaction cost economics", Journal of Economic Issues, Vol. XXXI, No. 1, March, pp. 39-57

Nancarrow, C. and Brace, I. (2000), "Saying the "right thing": Coping with Social Desirability Bias in Marketing Research", Bristol Business School Teaching and Research Review, Vol. 3, Summer, pp. $1468-1578$

Nesheim, T. (2001), "Externalization of the core: antecedents of collaborative relationships with suppliers", European Journal of Purchasing and Supply Management, Vol. 7, pp.217-225

Nunnally, J. (1978), Psychometric theory, (2nd ed.), New York: McGraw-Hill.

Owen, L., Goldwater, C., Choate, K. and Blitz, A. (2008), "Collaborative innovation throughout the extended enterprise”, Strategy and Leadership, Vol. 36 No 1. pp. 39-45

Parker, D. and Hartley, K. (2003), "Transaction costs, relational contracting and public private partnerships: a case study of UK defence", Journal of Purchasing and Supply Management, Vol. 9, pp. 97-108

Pearcy, D., Giunipero, L. and Wilson, A. (2007), "A Model of Relational Governance in Reverse Auctions" , Journal of Supply Chain Management, Vol. 43 No. 1, pp. 4-15

Perez, M.P., and Sanchez, A.M. (2001), "Suppler relations and flexibility in the Spanish automotive industry", Supply Chain Management: An International Journal, Vol. 6 No. 1, pp. 29-28

Peter, J. (1981), "Construct validity: A review of basic issues and marketing practices", Journal of Marketing Research, Vol. 18, No. 2, pp. 133-145.

Phillips, D. and Clancy, K. (1972), "Some effects of “Social Desirability" in Survey Studies", American Journal of Sociology, Vol. 77 No. 5, pp. 921-940

Pillai, K. and Sharma, A. (2003), "Mature relationships: Why does relational orientation turn into transaction orientation?", Industrial Marketing Management, Vol. 32, pp. 643-651

Ping, R. (1993), "The effects of satisfaction and structural constraints on retailer exiting, voice, loyalty, opportunism and neglect", Journal of Retailing, Vol. 69 No. 3, Fall, pp. 320-352

Podsakoff, P. M. and Dalton, D. R. (1987), "Research methodology in organizational studies", Journal of Management, Vol. 13 No. 2, pp. 419-441.

Podsakoff, P.M. and Organ, D.W. (1986), "Self-reports in organizational research: problems and prospects”, Journal of Management, Vol. 12 No.4, pp. 531-544.

Podsakoff, P., MacKenzie, S., Lee, J. and Podsakoff, N. (2003), "Common method biases in behavioural research: A critical review of the literature and recommended remedies", Journal of Applied Psychology, Vol. 88, pp. 879-903. 
Prajogo, D.I., Power, D.I., and Sohal, A.S. (2004), "The role of trading partner relationships in determining innovation performance: and empirical investigation", European Journal of Innovation Management, Vol. 7 No. 3, pp.178-186

Provan, K. and Gassenheimer, J. (1994), "Supplier commitment in relational contract exchanges with buyers: A study of interorganizational dependence and exercised power", Journal of Management Studies, Vol. 31 No. 1, pp. 55-68

Provan, K. \& Skinner, S., (1989), "Interorganizational dependence and control as predictors of opportunism in dealer-supplier relations", Academy of Management Journal, Vol. 32 No.1, pp. 202-212

Rahman, M. and Kumutasawamy, M. (2008), "Relational contracting and teambuilding: assessing potential contractual and noncontractual incentives", Journal of Management in Engineering, Vol. 24 No. 1, January, pp. 48-63

Ramsay, J. and Wagner, B. (2009), “Organisational Supplying Behaviour: Understanding supplier needs, wants and preferences", Journal of Purchasing \& Supply Management, Vol. 15 No. 2, pp. 127138

Ramsay, J. (2004), "Serendipity and the realpolitik of negotiations in supply chains", Supply Chain Management: An International Journal, Vol. 9 No. 3-4, pp. 219-229

Ramsay, J. (1996), "The case against purchasing partnerships", International Journal of Purchasing and Materials Management, Fall, pp. 13-19

Ramsay, J. and Wilson, I. (1990), "Sourcing/contracting strategy selection”, International Journal of Operations and Production Management, Vol. 10 No. 2, pp. 19-28

Randall, D., Huo, Y. and Pawelk, P. (1993), "Social desirability bias in cross-cultural ethics research", The International Journal of Organizational Analysis, Vol. 1 No. 2, pp. 185-202

Rebernick, M. and Bradac, B. (2006), "Cooperation and opportunistic behaviour in transformational outsourcing", Kybernetes, Vol. 35 No. 7/8, pp. 1015-1013

Richman, W., Kiesler, S., Weisband, S. and Drasgow, F. (1999), “A meta-analytic study of social desirability distortion in computer-administered questionnaires, traditional questionnaires and interviews", Journal of Applied Psychology, Vol. 84 No. 5, pp. 754-775

Rindfleisch, A. and Heide, J. (1997), "Transaction cost analysis: Past, present and future applications", Journal of Marketing, October, Vol. 61, pp. 30-54

Ring, P. and Van de Ven, A. (1994), "Developmental processes of cooperative interorganisational relationships", Academy of Management Review, Vol. 19 No.1, pp. 90-118

Robson, M., Spyropoulou, S. and Al-Khalifa, A. (2006), "Anxiety of dependency in international joint ventures? An empirical study of drivers and consequences of relationship insecurity", Industrial Marketing Management, Vol. 35, pp. 556-566

Ryu, S., Arslan, H. and Aydin, N. (2007), "The effect of interfirm dependence structures on governance mechanisms", Journal of Purchasing \& Supply Management, Vol. 13, pp. 17-25

Saccani, N. and Perona, M. (2007), "Shaping buyer-supplier relationships in manufacturing contexts: design and test of a contingency model", Journal of Purchasing and Supply Management, Vol.13 No.1, January, pp. 26-41

Sackett, P. and Larson, J., (1990), "Research strategies and tactics in industrial and organizational psychology", In Dunnette, M. and Hough, L., (Eds.), Handbook of industrial and organizational psychology (2nd ed., Vol. 1, pp. 419-489). Palo Alto, CA: Consulting Psychologists Press

Scarpello, V. And Campbell, J., (1983), "Job satisfaction: Are all the parts there?", Personnel Psychology, Vol. 36, pp. 577-600. 
Schmitt, N. (1994), "Method bias: The importance of theory and measurement", Journal of Organizational Behaviour, Vol. 15, pp. 393-398.

Sekaran, U. (2003), "Research Methods for Business: A Skill Building Approach", Wiley and Sons, Inc. U.S.

Shook, C.L., Adams, G.L., Ketchen, D.J. and Craighead, C.W. (2009), "Towards a "theoretical toolbox" for strategic sourcing", Supply Chain Management: An International Journal, Vol. 14 No. 1, pp. 310

Simatupang, T.M. and Sridharan, R. (2005), "Supply chain discontent", Business Process Management Journal, Vol. 11 No. 4, pp. 349-369

Smith, K. G., Smith, K. A., Olian, J., Sims, H. O’ Bannon, D. and Scully, J. (1994), “Top management team demography and process: the role of social integration and communication", Administrative Science Quarterly, Vol. 39, pp. 412-438

Snell, P. (2007), "Punishments not useful, say buyers", Supply Management, Vol. 29 March, p.6

Song, M. and Di Benedetto, A. (2008), "Supplier's involvement and success of radical new product development in new ventures", Journal of Operations Management, Vol. 26 No. 1, pp.1-22

Soosay, C.A., Hyland, P.W. and Ferrer, M. (2008), "Supply chain collaboration: capabilities for continuous innovation", Supply Chain Management: An International Journal, Vol. 13 No.2, pp. 160-169

Spekman, R. Kamauff, J. and Myhr, N. (1998), "An empirical investigation into supply chain management: a perspective on partnerships", International Journal of Physical Distribution \& Logistics Management, Vol. 3 No.2, pp. 53-67.

Stuart, F. (1997), "Supplier alliance success and failure: a longitudinal dyadic perspective", International Journal of Operations and Production Management, Vol. 17 No. 6, pp. 539-557

Su, Q., Song, Y-T. Li, Z. and Dang, J-X. (2008), "The impact of supply chain relationship quality on cooperative strategy", Journal of Purchasing and Supply Management, Vol. 14 No.

4, December, pp. 263-272

Svahn, S. and Westerlund, M. (2009), "Purchasing strategies in supply relationships", Journal of Business and Industrial Marketing, Vol. 24 No. 3/4, pp. 173-281

Thach, L. (1995), “Using electronic Mail to Conduct Survey Research”, Educational Technology, March April, pp. 27-31

Treacy, M. and Wiersema, F. (1993), "Customer intimacy and other value disciplines", Harvard Business Review, January-February, pp. 84-93

Tunca, T. and Zenios, S. (2006), "Supply auctions and relational contracts for procurement", Manufacturing and Service Operations Management, Vol. 8 No. 1, Winter, pp. 43-67

Velicer, W. F and Fava, U. (1998), "The effects of variable and subject sampling on factor pattern recovery”, Psychological Methods, Vol. 3, pp. 231-251.

Velicer, W. F. and Jackson D. N. (1990), "Component analysis vs. common factor analysis: Some further observations", Multivariate Behavioral Research, Vol. 25, pp. 95-112.

Vereecke, A. and Muylle, S. (2006), "Performance improvement through supply chain collaboration in Europe", International Journal of Operations and Production Management, Vol. 26 No. 11, pp. 1176-1198

Wagner, B.A., Macbeth, D.K. and Boddy, D. (2002), "Improving supply chain relations: and empirical case study”, Supply Chain Management: An International Journal, Vol. 7 No. 4, pp. 253-264

Wainer, H. and Kiely, G. L. (1987), "Item clusters and computerized adaptive testing: A case for testlets", Journal of Educational Measurement, Vol. 24, pp. 185-201. 
Walker, D.H., Hampson .T. K. and Peters, R. (2002), "Project alliancing vs. project partnering: a case of the Australian National Museum project", Supply Chain Management: An International Journal, Vol. 7 No. 2, pp. 83-91

Wanous, J., Reichers, A. and Hurdy, M., (1997), “Overall Job Satisfaction: How good are single-item measures?”, Journal of Applied Psychology, Vol. 82 No. 2, pp. 247-252

Wilkinson, T. and Young, L. (1994), "Business dancing - The Nature and Role of Interfirm Relations in Business Strategy", Asia-Australian Marketing Journal, Vol. 2 No. 1, pp. 69-79

Willamson, O. (1991), "Comparative economic organization: The analysis of discrete structural alternatives", Administrative Science Quarterly, Vol. 36, pp. 269-296

Williamson, O. (1985), "The economic institutions of capitalism", New York, NY: The Free Press

Williamson, O. (1975), "Markets and Hierarchies: Analysis and Anti-trust Implications", New York: The Free Press

Zheng, J., Roehrich, J. and Lewis, M. (2008), "The dynamics of contractual and relational governance: Evidence from long-term public-private procurement arrangements", Journal of Purchasing and Supply Management, Vol. 14 No. 1, March, pp. 43-54 


\section{Appendix 1 - survey items}

(Respondent characteristics)

1. Job title

2. Sector

Public

Private

Not-for-profit

3. Industry

Agriculture, forestry, and fishing

Mining and quarrying

Manufacturing

Wholesale and retail trade

Electricity, gas, and water supply

Construction

Accommodation and food services

Transportation and storage

Information and communication

Finance and insurance

Real estate

Professional services

Administrative and support services

Arts and entertainment

Other services

Public administration and defence

Education

Health and social work

4. Number of employees

$<10$ 10-30 31-50 51-100 101-250 >250

5. Number of suppliers

6. Number of years you have been involved in purchasing and dealing directly with suppliers $<2 ; 2-5 ; 5-10 ;>10$

\section{(Questions concerned with supplier empathy and its related constructs)}

7. In your experience, how effective are the following techniques in persuading suppliers to do what you would like them to do? (NB. if you have not used a technique, please tick 'don't know)

Extremely ineffective; Ineffective; Neither effective nor ineffective; Effective; Extremely effective; Don't Know

7a: Offering suppliers extended lead times

7b: Withholding or delaying payment to suppliers

7c: Offering supplier higher prices

7d: Using competitive pressure

7e: Offering suppliers technical assistance

7f: Paying suppliers more promptly

7g: Excluding suppliers from early knowledge of future business developments

7h: Threatening suppliers with loss of business

7i: Involving suppliers early in new business decisions 
8. Imagine you are a buyer for one of your competitors and you have a supplier that routinely cause problems. How significant do you think the following factors would be in creating a poor working relationship?

Extremely insignificant; Insignificant; Neither significant nor insignificant; Significant; Extremely significant; Don't know

8a: Lack of buying power

8b: Unreasonable personal behaviour of supplier's staff

8c: Poor supplier communication skills

$8 \mathrm{~d}$ : Lack of concern on the part of buyers for supplier's needs

8 e: Supplier's focus on other customers

8f: Unreasonable demands from the buyers

8g: Supplier generated quality problems

8h: Poor buyer communication skills

8i: Poor planning performance by the buyer's organisation

9. Different organisations in different markets have different sourcing policies. Which of the following statements most closely resembles your organisation's approach towards sourcing of important goods and services?

- Whenever possible we try to single-source such supplies.

- Whenever possible we try to have two suppliers of such supplies.

- Whenever possible we try to have more than two sources of such supplies.

- We do not have any specific sourcing strategies or polices with respect to such supplies.

10. Which of the following words most closely matches your organisation's primary strategic focus as a seller?

- Quality

- Speed of delivery

- Cost effectiveness

- Product / service innovation

- Don't know

11. The extent to which organisations rely on joint design work with their suppliers varies widely. How frequently does your organisation engage in joint design efforts with your suppliers?

- Never

- Extremely rarely

- Rarely

- Occasionally

- Frequently

- Extremely frequently

- Don't know

12. Does your purchasing organisations have any formal stated objectives concerning the need to form partnerships or strategic alliances or to be more cooperative with suppliers?

- Yes

- No

- Don't know

13. "Our personal interactions with long-term suppliers are significantly better than those with 
short-term suppliers"

- Strongly disagree

- Disagree

- Neither agree nor disagree

- Agree

- Strongly agree

14. The percentage of your suppliers that routinely cause you problems

- Non

- $10 \%$

- $20 \%$

- $30 \%$

- $40 \%$

- $50 \%$

- $60 \%$

- $70 \%$

- $80 \%$

- $90 \%$

- All 